\title{
Changing Landscape in Credit Management and Loan Performance: The Role of Central Bank Regulations in the Context of Commercial Banks in Kenya
}

Mburu, Muthoni Irene, Lucy Wamugo Mwangi, Stephen M.A Muathe

To Link this Article: http://dx.doi.org/10.6007/IJARBSS/v10-i12/8112

DOI:10.6007/IJARBSS/v10-i12/8112

Received: 12 October 2020, Revised: 09 November 2020, Accepted: 27 November 2020

Published Online: 18 December 2020

In-Text Citation: (Mburu et al., 2020)

To Cite this Article: Mburu, M. I., Mwangi, L. W., \& Muathe, S. M. . (2020). Changing Landscape in Credit Management and Loan Performance: The Role of Central Bank Regulations in the Context of Commercial Banks in Kenya. International Journal of Academic Research in Business and Social Sciences, 10(12), 116127.

Copyright: (c) 2020 The Author(s)

Published by Human Resource Management Academic Research Society (www.hrmars.com)

This article is published under the Creative Commons Attribution (CC BY 4.0) license. Anyone may reproduce, distribute, translate and create derivative works of this article (for both commercial and non-commercial purposes), subject to full attribution to the original publication and authors. The full terms of this license may be seen at: http://creativecommons.org/licences/by/4.0/legalcode

Vol. 10, No. 12, 2020, Pg. 116 - 127

Full Terms \& Conditions of access and use can be found at http://hrmars.com/index.php/pages/detail/publication-ethics 


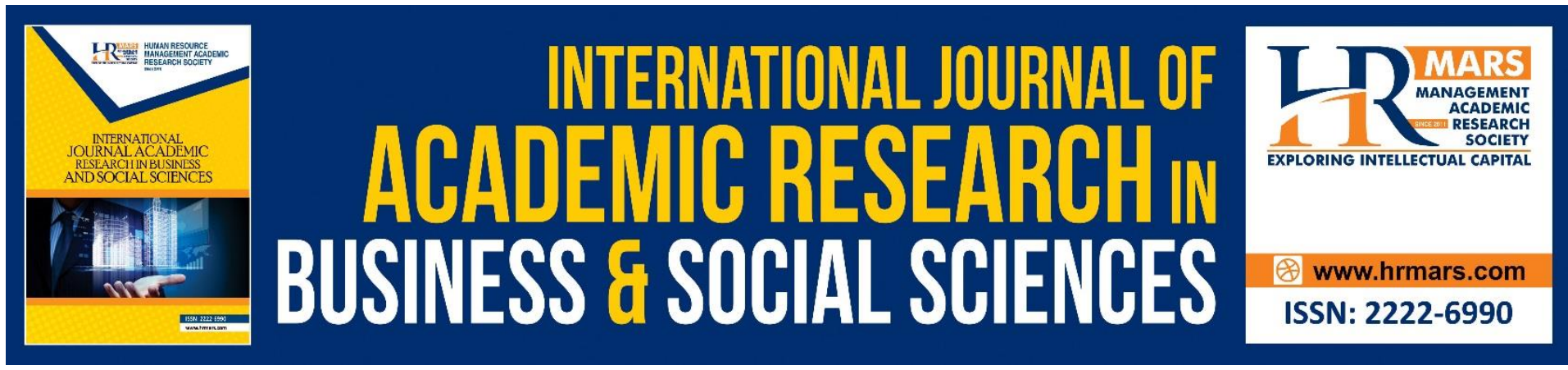

\title{
Changing Landscape in Credit Management and Loan Performance: The Role of Central Bank Regulations in the Context of Commercial Banks in Kenya
}

\author{
Mburu, Muthoni Irene, Lucy Wamugo Mwangi, Stephen M.A \\ Muathe \\ Department of Business Administration, School of Business, Kenyatta University
}

\begin{abstract}
Commercial banks in Kenya as per the World Bank report recorded higher non-performance in loans than the standard globally in spite of Kenya having the most stable and developed banking system in East and Central Africa region. Commercial banks non-performing loans for five years from 2015 to 2018 averaged eleven percent which was higher than the recommended rate of one percent. In Kenya, commercial banks' non-performing loans remain higher than the recommended rate which could be due to inadequate credit management practices. The study therefore aimed at examining the moderating role of the central bank regulations on the relationship between credit management practices and loan performance. The underpinning theory of the study was the credit risk theory. The study used explanatory research design and the research philosophy adopted was positivism. The target population was 44 commercial banks in Kenya and a census approach was used. Both primary and secondary data were used. Primary data was collected through structured questionnaires and related to credit management practices while secondary data was obtained from review of existing bank loan records in relation to loan amount advanced and non-performing loans for a period of four years from 2015-2018. Multiple regression analysis was used to test the study hypothesis. The study found out that Central Bank Regulations had no significant moderating effect on the relationship that exists between credit management practices and loan performance. Therefore, the study concluded that the moderating role of central bank regulations could not be confirmed. The study recommended that the central bank of Kenya to continuously assess and update credit management practices and the central bank regulations. The Government through regulating bodies should thus establish credit policies that regulate traditional and emerging credit practices among financial institutions.
\end{abstract}

Keywords: Central Bank Regulations, Credit Management Practices, Loan Performance, Commercial Banks in Kenya.

\section{Introduction}

Loan performance constitutes a huge proportion of the credit risk of a bank as it accounts for more than 10 times of the equity (Barth et. al., 2001). The total amount of money issued out 
as loans is referred to as loan portfolio to different borrowers as different loan products. The loan products could be in form of individual loans, corporate loans, salary loans or group guarantee loans. Loan performance accesses the rates of payment, number of borrowing clients, security pledged and rate of arrears recovery (Basel, 2006; Mburu, Mwangi, \& Muathe, 2020).

Commercial banks in Kenya have recorded higher non-performing loans than the standard globally (World Bank, 2018). According to Montana (2012), non-performing loans have continued to record sharp upward growth over the years despite the increasing efforts to curb non-performing loans. Non-performing loans have been increasing over the years. For instance, in Kenya non performing loans increased from 4.96\% in 2013 to 5.9\% in 2014, 8.97\% in 2015, 9.02\% in 2016, 11.38\% in 2017 and 14.92\% in 2018 (Central Bank of Kenya, 2018). In 2018, the NPLs in the banks were 14.92\% and four years average from 2015 to 2018 of $11.07 \%$ which was higher than the recommended rate of $1 \%$ (World Bank, 2018). According to Ekrami and Rahnama (2009) the high amounts of NPLs acts as an indication of the current high risk in credits in the banking system which poses both market and liquidity problems. NPLs mainly occur as a result of inefficiencies in the credit management practices employed by the banks (Morton, 2003).

Currently, credit management practices are considered as an integral component for the success of the banks (Lalon, 2015). This is attributed to the fact that commitment to the credit management practices ensures long term survival of the banking institutions through shielding from default loans (Kithinji, 2010). Poor credit management practices have adverse negative effects on the banks resulting in reduced profitability and liquidity problems due to compressed profit margins from the rising NPLs hence bringing about the most challenging environment for banks (Saunders \& Allen, 2010). In the past decade (2000-2010), most financial institutions were not keen in their efforts on timely credit recovery and consequent reduction of Non-Performing loans as today (Montana, 2012).

Central bank of Kenya in 2005 issued guidelines where banks were required to have debt collection policies procedures which included collection enforcements, guarantor payments and continuous monitoring and control of loans (CBK, 2015). In 2016, further guidelines were issued on the adequacy and enforceability of collateral or guarantees for strict adherence and compliance by commercial banks in Kenya (CBK, 2016). NPLs increase with debt collections going far more into the future. The need to reduce non-performing loans has seen commercial banks aim at reducing the collection period by adopting stringent collection policy (Otieno \& Nyagol, 2016). The effectiveness of the debt policy will be based on the minimization or elimination of defaults on loan repayment. Though Kenya has a well-developed commercial banking sector compared to most of Africa, it still faces challenges of loan administration and collection of loans (Otieno \& Nyagol, 2016).

Central bank of Kenya in an attempt to address deficiencies in credit management issued guidelines to be followed by commercial banks. Credit management guidelines were issued in 2005 where commercial banks were required to have client appraisal policy (CBK, 2005). Following the guidelines in 2015 , client appraisal policy was further reviewed to include credit referencing bureau review by commercial banks before credit could be advanced. This led to more advanced client appraisal technique among commercial banks and review of lending and debt collection policies (CBK, 2015).

Following the collapse of numerous commercial banks out of inadequate credit risk management, in 2016, CBK issued further guidelines on lending policy and classification of non-performing loans (Central Bank of Kenya, 2016). Lending policies needed to be 
commensurate with the size and complexity of the institution and be able to present a clear position on the commercial banks' exposure. Lending policies were also required to ensure transparency in the transactions relating to lending. Insider loans to directors and related parties were also required to be disclosed (Central Bank of Kenya, 2018).

The lending policies guide the bank on issuing out loans to customers and ensuring proper credit management (Kithinji, 2010). These should be aligned with the general bank plans and factors such as existing credit policies and prevailing country's economy status. Prior to the establishment of the lending policies, banks mainly issued out credit to anyone who expressed interest to borrow, this resulted in large volumes of bad credit leading the banks to be more cautious thereafter (Abor, 2004, Mburu, Mwangi, \& Muathe, 2020).

The banking sector operates on a legal framework established by the CBK. These regulations are meant to guide supervision and monitoring of deposit taking institutions such as banks and setting out requirements for their risk taking (Brownbridge, 2002). The regulations are essential contributor to minimizing and preventing financial related issues. The aim of the implemented regulations and guidelines is to assist the banking sector as well as other financial firms to be key players and ensuring longevity. The returns accrued are therefore higher as well as significant contribution to the economy (Ndungu, 2010).

Central Bank regulations are essential in establishing a well monitored and well set out rules for operation of financial activities with easy supervisions (Barth, Caprio and Levine, 2001). Lack of appropriate regulation is undesirable as it may lead to bank failures and systemic instability (Brownbridge, 2002). In Kenya, Central Bank regulations take the form of prudential guidelines issued by CBK in attempts to reduce the risk level that the bank creditors are faced with whilst ensuring the bank's asset and capital adequacy (Plosser, Kovner \& Hirtle, 2016, Onsongo, Muathe, \& Mwangi, 2019).

Following financial crisis in 2008, Central Banks across the world have required adoption of stringent credit management. The level of disclosure of non-performing loans has also been enhanced. The criteria of categorizing loans as non-performing loans have been adopted by Central Bank in Kenya among other federal banks globally in line with Basel III requirements. Commercial banks are now more than in the past required to analyze risks facing credit and constantly evaluate the risk facing the loans (Kairaria, 2014).

In Kenya, the commercial banks dominate the financial system whereby they act as intermediates between the deficits units of the economy and the surplus ones. Currently 44 banks are licensed and regulated by the CBK (CBK, 2017). The Kenyan banking sector has undergone many regulatory and financial reforms in the past. Such reforms have brought in important changes to the banking sector as well as inspiring foreign banks to enter the Kenyan market (Otieno \& Nyagol, 2016). The banking sector is governed by the Banking Act and including Prudential Guidelines. Commercial banks in Kenya are required by CBK to submit audited annual reports, which include their financial performance and in addition disclose various financial risks in the reports including liquidity risk, credit risk as well as management of credit risk.

\section{Statement of the Problem}

Loan performance remains the highest detrimental factor to development of the financial sector (World Bank, 2016) and impacts on banks' ability to lend (Doriana, 2015). There has been concern on the extent of non-performing loan levels in Kenya which has been higher than the recommended rate of $1 \%$. In 2018, banks NPLs to total loans were $14.92 \%$ and five years average of 11.07\% (World Bank, 2018). Between the year 2017 and 2018 the NPLs to 
total loans ratio increased from 11.38 percent to 14.92 percent (Central Bank of Kenya, 2018). Ineffective credit management practices have been identified to constitute a major reason behind these banking difficulties (Basel, 2006).

In Kenya, the recent collapse of some commercial banks shows that the successful utilization of the credit management practices is yet to be realized (Kinyua, 2017). According to Obiero (2013), $37.8 \%$ of banks collapsed due to poor lending practice between 1984 and 2013. Taking the case of Chase Bank which was placed into receivership in 2016 due to insolvency as a result of huge non performing loans and CBK Prudential Guidelines on capital adequacy of minimum core capital to total risk weighted assets. In October 2015 the CBK put Imperial Bank under statutory management due to unsafe and unsound credit management practices (CBK, 2016).

Further, studies undertaken on moderating role of central bank regulations, credit management practices and loan performance have not been conclusive. For instance Oretha (2012) investigated the effect of CRM practices on the financial performance of Liberian banks but did not examine how the credit risk management practices affected loan performance. Gakure et al (2012) conducted a study on the relationship between credit management techniques and the performance of commercial banks in Kenya but did not show how various credit management techniques affect loan performance. Otieno and Nyagol (2016) conducted a study on the effect of credit management on the financial performance of microfinance banks.

Past studies had adopted different methodologies in relation to the data and research design. Most studies including Chikamai and Mutua (2018), Makori and Sile (2017) and Muasya (2013) used descriptive research design using only primary data. Therefore, studies conducted on credit management practices do not exhaustively show how credit management practices such as debt collection policy, client appraisal and lending policy affect loan performance in commercial banks. However, this study used an explanatory research design. Since, loan nonperformance continues to be a major challenge to commercial banks in Kenya, this study focused on the effect of credit management practices on loan performance of commercial banks in Kenya.

\section{Objective of the Study}

The objective of the study is to examine the moderating effect of the Central Bank Regulations on the relationship between credit management practices and loan performance of commercial banks in Kenya.

\section{Literature Review}

This is a discussion of the available literature pertaining to the study which includes the theoretical literature as well as the empirical literature.

\section{Theoretical Review}

The study was guided by Credit Risk Theory proposed by Melton, (1974) which provides a foundation through which financial institutions are able to not only measure but also manage credit risk exposure. The theory views default of loans to an embedded put option which is available to the borrower when the circumstances are economically favorable for the borrower to exercise their option to default. Crosby et al, (2003) further adds that currently the main credit risk analysis methods include structural approach, appraisal form and information completeness approach as per Credit Risk Theory. 
The importance of the theory to the study is that it describes the procedures in credit risk management by providing an option-theoretic framework which may be individualized for specific borrowers and used as a basis for modeling the default occurrence. The theory affirms that credit management practices is dynamic and has a standard approach to managing and mitigating the risk. It provides a framework which may be utilized in assessing any particular credit risk being faced by the bank hence resulting in improved performance of the loans in commercial banks.

\section{Empirical Literature Review}

Balgova, Nies and Plekhanov (2016) investigated influence of NPLs on economic performance. Longitudinal design was used. The study established that reducing non-performing loans has an unambiguously positive medium-term impact on the economy. The study failed to examine how credit management practices affected loan performance. However, the study confirmed the negative consequences of NPLs in an economy and hence need to manage the same. The current study determined how credit management practices affect loan performance.

Otieno and Nyagol (2016) investigated on CRM practices and performance. Descriptive research design was adopted by the study. The research results were that the parameters of credit management had a significant negative correlation with the performance measures. The research did not explore how credit risk management affected loan performance but rather looked at performance in general of which the results can only be applied on performance. However, the study confirmed the importance of managing credit risks on performance. The current study explored how credit management practices affect loan performance.

Plosser, Kovner and Hirtle (2016) studied the impact of supervision on bank performance. Using a matched sampling approach, the study found that the top banks were least volatile, had less risky loan portfolios and further engaged in more conservative practices. The findings thus confirmed importance of bank regulation even though the study did not relate bank supervision to loan performance. The study related supervision to bank performance and also paid attention to one aspect central bank regulations which the results may not be generalized to other aspects. The current study related bank supervision to performance of loans and looked at other aspects of central bank regulations.

Ahmed and Malik (2015) examined on loan performance and CRM taking empirical evidence from Pakistan. Multiple regression analysis was used. The study found that client appraisal and credit terms had a significant positive influence on the loan performance whereas collection policy and credit risks had a positive but insignificant influence on how the loans performed. The study was based in Pakistan which has different social and economical structures from those in Kenya. The current study looked at the specific practices affecting loan performance of commercial banks in Kenya.

Kairaria (2014) investigated the relationship between capital adequacy requirements on creation of credit facilities in Kenya. Causal research design was used. The study revealed that introduction of capital adequacy mandatory requirement negatively affected the profitability of the banking sector. The study however did not assess the impact of capital adequacy requirement on loan performance which was addressed by the current study.

Ofonyelu and Alimi (2013) studied how the bank's risk on borrowers affected NPLs. The study used descriptive research design. The study found that NPLs could be reduced through credit analysis which involves analytical manipulation. While the study confirmed the importance of 
credit management in managing loans, the study did not document the specific components affecting how loans performed which is crucial in assessing the effect of loan performance. The specific components relating to credit management were examined in the current study. Gakure et.al. (2012) examined on credit management techniques and banks performance of unsecured loans. The study used descriptive research design. The study indicated that credit management techniques had a positive effect on the banks performance. Although the study did not examine the various credit management techniques and their effect on loans, the study confirmed the importance of credit management among commercial banks in meeting banks objectives. The current study examined credit management techniques and their effect on loans performance.

Moti, (2012); Darwish et al (2018) conducted a study on the efficiency of credit management system on the performance of loans in the MFIs in Kenya. The study adopted a descriptive research design and research analysis was undertaken using inferential analysis. It was found that credit management practices had only minimal effect on the loan performance. The study did not use both secondary and primary data and hence affecting reliability of the findings and also was done on micro finance sector which may not be generalized to other sectors in Kenya. The current study therefore used both secondary and primary data and studied the loan performance of commercial banks in Kenya.

Aigbogun (2011) studied prudential guidelines and profitability of the banking sector in Nigeria. Descriptive research design was used. Findings showed that there was increased need for bank supervision from the regulatory bodies. The bank's prudential guidelines had helped to check the mismatch between banks' reported and actual profits and also ensured early detection of fraud, distress and deterioration of banks credit portfolio. The study was however done in Nigeria and not in Kenya and whether these findings would be the same wasn't established. The study did not also relate prudential guidelines to loan performance. The current study was done in Kenya and related prudential guidelines to loan performance. Ismail (2011) examined the impact of prudential guidelines and deregulation on the Nigerian banking industry. Using a descriptive research design, the study revealed that while the giant banks were positively affected by the regulation and returned them to profitability and sanity, small banks performance reduced. The guidelines also made banks to classify their loans as performing and non-performing by reducing their risk of incoming bad debts. The study was done in Nigeria which is different from the Kenyan banking sector. The study therefore confirms the importance of prudential guidelines in terms of reporting performing and nonperforming loans and thus the reason for incorporating the same as a moderating variable. Based on the reviewed empirical literature it was hypothesized that:

$\mathrm{H}_{0}$ : Central Bank Regulations have no moderating effect on the relationship between credit management practices and loan performance of commercial banks in Kenya.

\section{Research Methodology}

The study adopted explanatory research design. Explanatory research design focuses on determining the relationship between elements and what causes the existing association. The research adopted positivism philosophy because the events of interest were objective and the researcher was independent. The target population for this study was all the 44 commercial banks with branches in Kenya. The study targeted all the 44 heads of credit department located at the commercial banks head offices. This population was chosen as they 
are directly involved with the credit management practices in the banks hence the most conversant with the study topic.

The study used both primary data and secondary data where primary data for the study was collected using a close-ended questionnaire. Further, the researcher used secondary data using secondary data collection sheet from the existing banks financial records in relation to the number of loans advanced and amount of non-performing loans. Secondary data was collected for a period of four years from 2015-2018. Inferential statistical measures included multiple regression analysis to test the relationship between the research variables.

\section{Findings and Discussion}

The study sought to examine the moderating effect of the Central Bank Regulations on the relationship between credit management practices and loan performance of commercial banks in Kenya. To achieve this, multiple regression analysis using path analysis technique was conducted. In the first step, regression analysis was done where the various credit management practices were regressed against loan performance.

In the second step, Central bank regulations and the interaction terms between debt collection policy, client appraisal, lending policy and Central bank regulations were regressed against loan performance. The model summary findings are presented in Table 1 below.

Table 1: Model Summary for Moderating Effect of the Central Bank Regulations

\begin{tabular}{lllll}
\hline Model & $\mathbf{R}$ & R Square & Adjusted R Square & Std. Error of the Estimate \\
\hline & $.823^{\mathrm{a}}$ & .677 & .651 & 4.78081 \\
2 & $.895^{\mathrm{b}}$ & .802 & .760 & 3.96663 \\
\hline
\end{tabular}

a. Predictors: (Constant), Debt Collection Policy, Client Appraisal, Lending Policy

b. Predictors: (Constant), Debt Collection Policy, Client Appraisal, Lending Policy, Central Bank Regulations, Debt Collection Policy and Central Bank Regulations, Client Appraisal and Central Bank Regulations, Lending Policy and Central Bank Regulations

The Adjusted R squared for the relationship between debt collection policy, client appraisal, lending policy and loan performance was 0.651 , which implied that $65.1 \%$ of the loan performance can be explained by debt collection policy, client appraisal and lending policy. However, in the second model, in Table 1 above, which constituted of debt collection policy, client appraisal, lending policy, central bank regulations, debt collection policy and central bank regulations, client appraisal and central bank regulations, lending policy and central bank regulations, the adjusted r-squared was 0.760 . The introduction of central bank regulations in the second model led to an increase in adjusted $r$-squared from $65.1 \%$ to $76 \%$ showing that central bank regulations positively moderates the relationship between credit management practices and loan performance of commercial banks in Kenya.

Table 2: ANOVA for Moderating Effect of the Central Bank Regulations

\begin{tabular}{lllllll}
\hline Model & & Sum of Squares & Df & Mean Square & F & Sig. \\
\hline 1 & Regression & 1773.955 & 3 & 591.318 & 25.871 & $.000^{\mathrm{b}}$ \\
& Residual & 845.677 & 37 & 22.856 & & \\
& Total & 2619.632 & 40 & & & \\
2 & Regression & 2100.405 & 7 & 300.058 & 19.071 & $.000^{\mathrm{c}}$ \\
& Residual & 519.226 & 33 & 15.734 & & \\
& Total & 2619.632 & 40 & & & \\
\hline
\end{tabular}

a. Dependent Variable: Loan Performance 
performance.

The results also show that introducing the moderating variable (central bank regulations) in the regression model, the effect of client appraisal on loan performance, became significant $\left(\beta_{2} X=-11.112, p\right.$-value $\left.=0.032\right)$. The interaction between client appraisal and central bank regulation was not significant $\left(\beta_{2} X=2.568, p\right.$-value $\left.=0.07\right)$. Therefore client appraisal practices did not vary with the Central Bank Regulations. This inferred that Central Bank Regulations did not moderate the relationship between client appraisal and loan performance. The results further show that by introducing the moderating variable (central bank regulations) in the regression model, the effect of lending policy on loan performance became insignificant $\left(\beta_{3} X=3.545, p\right.$-value $\left.=0.392\right)$. The interaction term between lending policy and central bank regulation was insignificant $\left(\beta_{3} Z=1.217, p\right.$-value $\left.=0.415\right)$. This inferred that central bank regulations did not moderate the relationship between lending policy and loan performance. By substituting the beta values as well as the constant term, model emanating from the regression model was as follows:

$Y=14.123+5.727 X_{1}-11.112 X_{2}+3.545 X_{3}-9.450 Z-0.834 X_{1} Z+2.568 X_{2} Z+1.217 X_{3} Z+\varepsilon$

Where; $Y=$ Dependent variable: Average Loan Performance; $X_{1}=$ Debt Collection Policy; $X_{2}=$ Client Appraisal; $X_{3}=$ Lending Policy; and $Z$ is the hypothesized moderator (Central Bank Regulations)

The results of the moderating effect of central bank regulation on the relationship between credit management and loan performance was not confirmed by the study. The findings relate to those of Ismail (2011) who found that while the giant banks were affected by the regulation and returned them to profitability and sanity, small banks performance reduced. The findings agreed with those of Plosser, et al., (2016) who found Central bank regulations were crucial in determining the risk management practices. Kairaria (2014) also found that central bank regulations impacted on credit management practices adopted by commercial banks. Aigbogun (2011) studying prudential guidelines and performance of commercial banks in Nigeria concluded that there was increased need for bank supervision to check the mismatch between banks' reported and actual profits and also ensured early detection of fraud, distress and deterioration of banks credit portfolio.

\section{Conclusions and Policy Implication}

The moderating effect of Central Bank Regulations on the relationship between credit management practices and loan performance of commercial banks in Kenya was not confirmed. The study concluded that the Central Bank Regulations affected loan performance of commercial banks but credit management practices did not vary with central bank regulations.

The study recommended that the Central Bank of Kenya to continuously assess and update the best practices relating to central bank regulations. Monitoring of the compliance by commercial banks to the prudential guidelines will also be vital. This will ensure compliance by the banks on improved credit management by commercial banks and thus improving loan performance.

\section{Theoretical and Contextual Contribution}

The study is significant to investors as it will avail information on the influence of returns on their investments. To commercial banks and financial sector, this study will provide an insight into the credit risk attributes which may need to be incorporated in their loan awards process and the factors that determine success of administration of loans. To the general public, the 
study will lead to improved performance of loans. Researchers and Scholars will find this study important in facilitating an increase in the information related to the area of concern.

\section{References}

Abor, J. (2004). Internationalization and Financing Options of Ghanaian SMEs, ACTA Commercii, 4, 60-72.

Ahmed, S., \& Malik, A. (2015). Credit management and Loan Performance: Empirical Investigation of Micro Finance Banks of Pakistan. International Journal of Economics and Financial Issues, 5(2), 574-579.

Aigbogun, F. (2011). Perceived Impact of Prudential Guidelines on the Services and Performance of Commercial Banks in Nigeria. MBA Project, University of Nigeria.

Altunbas, Y., Gambacorta, L., \& Marques-Ibanez, D. (2009). Bank risk and monetary policy. ECB Working Paper 1075.

Balgova, M., Nies, M., \& Plekhanov, A. (2016). Economic Impact of Reducing Nonperforming Loans. European Bank, Working Paper No. 193.

Bank for International Settlements. (2016). Basel Committee on Banking Supervision: Prudential treatment of problem assets - definitions of non-performing exposures and forbearance. Consultative Document, Bank for International Settlements

Barth, R., Gerard, C.,\& Ross, L. (2001). Bank Regulation and Supervision: What Works Best?,World Bank Working Paper 2725.

Basel. (2006). Principles for the Management of Credit Risk, Consultative paper issued by the Basel Committee on Banking Supervision, Basel.

Basel, III. (2017). Basel III reforms. Basel Committee on Banking Supervision: Bank for International Settlements. https://www.bis.org/bcbs/basel3.htm.

Brownbridge, M., \& Kirkpatrick, C. (2002). "Financial Sector Regulation: The Lessons of the Asian Crisis", Development Policy Review Vol 17 No 3, pp243- 266.

Central Bank of Kenya. (2005). Risk Management Guidelines. Nairobi. Central Bank of Kenya.

Central Bank of Kenya. (2016). Bank Supervision Annual Report 2016. Central Bank of Kenya, accessed on March 23, 2017 from

https://www.centralbank.go.ke/uploads/399346751_2016\%20Annual\%20Report.pdf

Central Bank of Kenya. (2018). Bank Supervision Report. Retrieved from https://www.centralbank.go.ke/

Central Bank of Kenya. (2017). CBK annual supervision report.www.centralbank.go.ke.

Crowley, J. (2007). Interest Rate Spreads in English-Speaking Africa.IMF Working Paper, 12345.

Darwish, S., Abdo, H., \& AlShuwaiee, W. M. (2018). Opportunities, challenges and risks of transition into renewable energy: the case of the Arab Gulf Cooperation Council. International Energy Journal, 18(4).

Doriana, C. (2015). The Impact of Non-performing Loans on Bank Lending Behavior: Evidence from the Italian Banking Sector. Eurasian Journal of Business and Economics, 8(16), 5971.

Gakure, R. W., Ngugi, J., Ndwiga, P. M., \& Waithaka, S. (2012). Effect of credit management techniques on the performance of unsecured bank loans employed commercial banks in Kenya. International Journal of Business and Social Research, 2,4, 31-45.

Ismail, Y. (2011). The Impact of Prudential Guidelines and Deregulation on the Nigerian Banking Industry. A Case Study of Union Bank Nigeria PLC, MBA project, University of Zaria. 
Kairaria, J. (2014). The Effect of Capital Adequacy Requirement on Credit Creation by Commercial Banks in Kenya.International Finance Journal, 2, 6, 34-47

Kinyua, A. (2017). Effects of Credit management Practices On Loan Performance Of Commercial Banks In Nyeri County, Kenya. European Journal of Economic and Financial Research 2(2).

Kithinji, A. M. (2010). Credit management and profitability of commercial banks in Kenya. International Journal of Finance, 2 (II), 201-216.

Lalon, R. (2015). Credit management (CRM) Practices in Commercial Banks of Bangladesh: "A Study on Basic Bank Ltd." International Journal of Economics, Finance and Management Sciences, 4, 8, 211-231

Mburu, I. M., Mwangi, L. W., \& Muathe, S. M. A. (2020). Credit Management Practices and Loan Performance: Empirical Evidence from Commercial Banks in Kenya. International Journal of Current Aspects in Finance, Banking and Accounting; Vol. 2 Issue 1. PP 5163

Moti, H. (2012). Effectiveness of Credit Management System on Loan Performance: Empirical Evidence from Micro Finance Sector in Kenya. International Journal of Business, Humanities and Technology, 2, 6, 99- 108.

Ofonyelu, C. C., \& Alimi, S. R. (2013). Perceived Loan Risk and Ex Post Default Outcome:Are the Banks' Loan Screening Criteria Efficient? Asian Economic and Financial Review, , 3(8), 991-1002.

Ombaba, M. K. (2013). Assessing the Factors Contributing to Non-Performance Loans in Kenyan Banks, European Journal of Business and Management, , 5(32), 155-162.

Onsongo, S. K., Muathe, S., \& Mwangi, L. (2019). Firm Size, Operational Risk and Performance: Evidence from Commercial Banks and Services Companies Listed in Nairobi Securities Exchange. International Journal of Current Aspects 3 (VI), PP. 372-379

Otieno, S., \& Nyagol, M. (2016). Relationship between Credit management and financial performance: empirical evidence from microfinance banks in Kenya. Research Journal of Finance and Accounting, 7 .6, 115-142

Plosser, M., Kovner, A., \& Hirtle, B. (2016).The Impact of Supervision on Bank Performance.Federal Reserve Bank of New York Staff Reports, no. 768

Saunders, A., \& Allen, L. (2010). Credit management in and out of the financial crisis: New approaches to value at risk and other paradigms. John Wiley \& Sons.

World Bank (2016). Databank: World Development Indicators. Accessed on March 21, 2017 fromhttp://databank.worldbank.org/data/reports.aspx?source=2\&series=FB.AST.NP ER.ZS\&country 